and Young Farmers' Clubs in England and Wales and in Scotland. Publication of the full report on the exploratory work on mixed clubs for young people of both sexes is anticipated early this year. Grants have also been made for the training of potential youth leaders, but the experiment with youth service camps in Oxfordshire has proved unsuccessful and has been discontinued. The Music Education Committee is encouraging the establishment throughout England and Wales of county music committees to co-ordinate all amateur musical activities in the administrative county areas and to foster new developments. The joint Committee for Drama seeks to promote the establishment of county drama committees and the appointment of county drama organizers. Contributions to the Land Settlement Association have been considerably reduced, but grants to the National Council of Social Service have continued at the $£ 5,000$ level in 1940-41-42. In addition, a grant of $£ 3000$ to the Y.M.C.A. has enabled the Association to continue its scheme of training boys for farm work and placing them in permanent positions on the land; more than six hundred boys were successfully trained and placed during 1941 .

\section{New Zealand Earthquakes}

According to a bulletin just received from the Dominion Observatory, Wellington, twelve strong earthquakes were registered during February 1942 by the thirteen seismographic stations in New Zealand. The interpretation of many of the seismograms was hindered by microseisms, though it is thought that the earthquake of February 17, the preliminary waves from which arrived at Wellington at $04 \mathrm{~h}, 18 \mathrm{~m} .24 \mathrm{~s}$. U.T., had its epicentre in the Coral Sea. A good deal of minor activity, which is expected in New Zealand, was recorded, and many local shocks were reported as having been felt by observers throughout the islands. The highest intensity reached was 6 on the Rossi-Forel scale (ringing of bells, stopping of clocks, breaking of windows, etc.), which occurred on two occasions : on February 21 at $22 \mathrm{~h} .23 \cdot 9 \mathrm{~m}$. U.T., felt at New Plymouth, and on February 22 at $12 \mathrm{~h}$. $18 \cdot 1 \mathrm{~m}$. U.T., felt at Whakatane and Opotiki, and followed by numerous minor shocks.

\section{Earthquakes Registered in Switzerland}

From October 1, 1941, until January 31, 1942 (bulletins just received from Zurich), fifty strong earthquakes were registered by the seismographs at Chur, Basel, Neuchâtel and Zurich. Some of these earthquakes were local (that is, in Switzerland), and others have been noticed previously in NATURE. Two, which have not been mentioned previously, occurred in Italy. They were on November 10, 1941, with epicentre near Lago di Garda, $e P$ being registered at Chur at $03 \mathrm{~h} .29 \mathrm{~m} .21 \cdot 8 \mathrm{~s}$. U.T., and on January 2, 1942, with epicentre in the neighbourhood of Trento, $e P$ being recorded at Zurich at $09 \mathrm{~h} .00 \mathrm{~m}$. $41 \cdot 2$ s. U.T.

\section{Leprosy in Brazil}

ACCORDING to the Journal of the American Medical Association of April 4 the prevalence of leprosy in Brazil is comparable to that of the U.S.S.R., which has about 170,000 lepers to 170 millions of population. There are now sixteen modern leprosariums, where 15,173 patients were isolated on December 31, 1941 . In the State of São Paulo more than 90 per cent of the contagious cases are isolated in six leprosariums, about 2,500 cases are isolated in the State of Minas Gerais and about 1,000 in the State of Para. There are 15 preventoriums where the healthy children of lepers are interned and many more institutions of the kind are being organized. Since 1938 the technique of infiltrations of the lesions through multiple local injections of chaulmoogra oil has been increasingly used with good results. The epidemiology of leprosy in Brazil is now being investigated. About 25 per cent of the cases are of the purely nervous form. The disease is more prevalent in males than in females and in coloured natives than in white Brazilians. The prevalence is also higher in white foreign people and in white foreign-born Brazilians than in white native-born Brazilians.

\section{University College, Exeter : Air-raid Damage}

DURING recent air attacks on Exeter, certain parts of University College were damaged. Some damage was done to the Botany Laboratories, the office building and the Handicraft Centre were completely burnt out, considerable damage was done to the new Library and two halls of residence. All the glasshouses, potting sheds, storehouses, etc., on the College estate were destroyed.

\section{Comet Grigg-Skjellerup}

A TELEGRAM from Tokyo has been transmitted by Strömgren announcing the discovery of this comet by Kanna Sekituti. Its position on May 9d. 11h. U.T. was R.A. $7 \mathrm{~h} .10 \mathrm{~m}$., Dec. $11^{\circ} 46^{\prime} \mathrm{N}$. 'The magnitude is given as 10 .

In the "Handbook of the British Astronomical Association", 1942, Mr. F. R. Cripps has provided the elements and an ephemeris for this comet. The position is very close to that given in the "Handbook", and the object can be easily found from the ephemeris without any corrections.

\begin{tabular}{|c|c|c|c|c|c|c|c|}
\hline \multicolumn{2}{|c|}{ Date } & \multicolumn{2}{|c|}{ R.A. } & \multicolumn{2}{|c|}{ Dec. } & $r$ & $\rho$ \\
\hline June & $10 \cdot 0$ & & $48 \cdot 6 \mathrm{~m}$ & $+31^{\circ}$ & $53 \cdot 8$ & 0.899 & $0 \cdot 370$ \\
\hline & 18 & 11 & $02 \cdot 5$ & 38 & $12 \cdot 4$ & 0.944 & 0.338 \\
\hline & 26 & 12 & $33 \cdot 3$ & 41 & $39 \cdot 1$ & 0.999 & 0.331 \\
\hline July & 4 & 14 & $03 \cdot 7$ & 40 & $36 \cdot 7$ & $1 \cdot 064$ & $0 \cdot 348$ \\
\hline & 12 & 15 & $15 \cdot 7$ & 36 & $15 \cdot 2$ & $1 \cdot 135$ & 0.388 \\
\hline & 20 & 16 & $07 \cdot 9$ & 30 & $42 \cdot 7$ & $1 \cdot 210$ & 0.445 \\
\hline & 28 & 16 & $45 \cdot 6$ & 25 & $16 \cdot 2$ & $1 \cdot 288$ & 0.515 \\
\hline
\end{tabular}

\section{Announcements}

AT the anniversary meeting of the Linnean Society of London held on May 28, the following were elected officers for the year 1942-43: President, Dr. E. S. Russell; Treasurer, Major F. C. Stern; Deputy Treasurer, Dr. B. Barnes; Secretaries, Mr. I. H. Burkill (botany) and Dr. Malcolm Smith (zoology). The new members of Council are Dr. G. S. Carter, Dr. F. C. Fraser, Mr. C. C. Hentschel, Dr. N. A. Mackintosh and Dr. R. Melville.

The National Institute of Hygiene, which was recently founded in Paris, will consist of four depart. ments devoted respectively to epidemiology, general hygiene, problems of nutrition and social diseases (cancer, syphilis, tuberculosis and alcoholism). Each department will be provided with laboratories. The institute will be under the authority of the State Secretary for Family and Health. A National Institute for Social Insurance has also been founded in Paris and will be under the authority of the State Secretary of Labour. 